J-SANAK: Jurnal Kajian Anak

(p-ISSN: 2686-5343 |e-ISSN: 2715-7989)

Vol. (1)(2), (Januari-Juni)(2020), (Halaman)(47-61)

DOI: https://doi.org/10.24127/j-sanak.v1i02.203

\title{
PENDIDIKAN ANAK USIA DINI MENURUT PEMIKIRAN IBNU QAYYIM AI-JAUZIYAH
}

\author{
Juli Afnita \\ Universitas Islam Negeri Sunan Kalijaga Yogyakarta \\ juli.afnita@yahoo.com \\ Maemonah $^{2}$ \\ Universitas Islam Negeri Sunan Kalijaga Yogyakarta \\ maemonah@uin-suka.ac.id
}

\begin{abstract}
ABSTRAK
Pada penelitian ini dilatar belakangi bagaimana cara-cara mendidik anak sejak dini. Dalam mendidik anak usia dini menjadi salah satu yang harus dikembangkan dengan segala potensinya. Oleh karena itu, dalam lingkup keluarga pada anak usia dini, ia memperoleh pendidikan pertamanya adalah kedua orangtua,yang telah diberikan amanah juga tanggung jawab. Namun kenyataannya terkadang orangtua kurang interaksi terhadap anaknya dan juga rasa kepeduliannya. Sehingga anak juga tidak adanya interaksi yang baik terhadap orangtua, keluarga, orang tedekat , maupun lingkungannya.Metode yang digunakan dalam penelitian adalah metode penelitian kepustakaan ( Library Research), dengan pendekatan kualitatif.Dari permasalahan yang dibahas, maka peneliti menggunakan pendekatan filosofis. Sehingga yang menjadi Objek dalam penelitian adalah pemikiran pendidikan anak usia dini menurut Ibnu Qayyim al-Jauziyah.Pada teknik pengumpulan data, maka peneliti menggunakan bahan-bahan dokumentasi. Dan pada peneliti itu sendiri adalah sebagai instrument inti. Peneliti menggunakan kajian isi ( content analysis ).Berdasarkan hasil penelitian pendidikan anak usia dini menurut pemikiran Ibnu Qayyim sangat penting bagi pendidikan anak sejak dini. Oleh karena itu, keluarga maupun orangtuanya dapat menjadi peran dalam bertanggung jawab bagi anak usia dini yang memberikkan pendidikan dengan baik sehingga anak dapat mengembangkan segala potensinya menjadi anak yang berakhlakul karimah, cerdas, dan mematuhi segala aturan dalam agama islam.
\end{abstract}

Kata Kunci:Pendidikan, Perkembangan anak, Pemikiran Ibnu Qayyim

Received: 08-05-2020; Received in revised: 26-06-2020- ; Accepted: 26-06-2020.

\section{ABSTACT}

In this research, the background is how to educate children from an early age. In educating early childhood is one that must be developed with all its potential. 
J-SANAK: Jurnal Kajian Anak

(p-ISSN: 2686-5343 |e-ISSN: 2715-7989)

Vol. (1)(2), (Januari-Juni)(2020), (Halaman)(47-61)

DOI: https://doi.org/10.24127/j-sanak.v1i02.203

Therefore, in the scope of the family in early childhood, he gets his first education is both parents, who have been given the mandate also responsibility. But the reality is sometimes parents lack interaction with their children and also their sense of caring. So that children also do not have a good interaction with parents, families, people, and the environment. The method used in research is the method of library research (Library Research), with a qualitative approach. Of the problems discussed, the researcher uses a philosophical approach. So that the object of research is the thought of early childhood education according to Ibn Qayyim al-Jauziyah. In data collection techniques, the researchers used documentation materials. And the researchers themselves are the core instrument. Researchers use content analysis (content analysis). Based on the results of early childhood education research according to Ibn Qayyim's thinking is very important for children's education from an early age. Therefore, family and parents can be a role in being responsible for early childhood who provide education well so that children can develop all their potential to be children who have morality, intelligent, and comply with all the rules in the Islamic religion.

Keywords:Education, Child development, Thought of Ibn Qayyim

\section{A. PENDAHULUAN}

Pendidikan khususnya di PAUD ( Pendidikan Anak Usia Dini ) harus mengetahui bagaimana cara-cara mendidik anak dari sejak dini. Agar adanya proses pendidikan maupun pengajaran yang diterapkan kepada anak(Syamsu Mappa, dick, 1984). Anak yang yang pada hakikatnya merupakan seorang generasi penerus untuk masa depan (Anggi Aggraeni Islami, Rifki Rosyad, 2020). Anak juga tidak mampu berkembang dengan sendirinya, apabila tidak adanya bimbingan maupun arahan yang baik oleh orangtuanya. Oleh karena itu, dalam lingkup keluarga, pendidikan pertama yang didapatkan oleh anak yaitu dari orangtuanya yang telah menerima amanah serta tanggung jawab terhadap anak. ( Mansur, 2001 ).

Adapun salah satu cara dalam mendidik anak yang dapat dilakukan oleh orangtua yaitu dengan adanya hubungan maupun interaksi yang diciptakan dengan baik bersama anak dilingkup keluarga maupun dilingkungan sekitarnya ( Aslan, 2019 ). Namun kenyataannya terkadang orangtua kurang adanya interaksi maupun rasa kepedulian terhadap anak, yang dapat membuat anakjuga tidak adanya interaksi yang baik dengan orangtua, keluarga, orang terdekat, maupun dilingkungannya ( Ahmad Kholil, 2006).

Dalam hal ini, seperti dalam studi kitab Tufah al-Maudud bi Ahkam alMaulud, yang dikutip oleh Arief Rifkiawan Hamzah. Beberapa rumusan masalah pada anak usia dini yaitu sebagai berikut:1) Bagaimana konsep pendidikan 
J-SANAK: Jurnal Kajian Anak

(p-ISSN: 2686-5343 le-ISSN: 2715-7989)

Vol. (1)(2), (Januari-Juni)(2020), (Halaman)(47-61)

DOI: https://doi.org/10.24127/j-sanak.v1i02.203

prenatal menurut Ibnu Qayyim Al-Jauziyyah dalam Kitab Tuhfah al-Maudud bi Ahkam al-Maulud, 2) Bagaimana implikasi pendidikan prenatal menurut menurut Ibnu Qayyim Al-Jauziyyah dalam Kitab Tuhfah al-Maudud bi Ahkam al-Maulud terhadap calon penggantin , 3) Bagaimana implikasi pendidikan prenatal prenatal menurut Ibnu Qayyim Al-Jauziyyah dalam Kitab Tuhfah al-Maudud bi Ahkam alMaulud terhadap perkemabangan potensi-potensi anak. Hal tersebut dapat menjadi perhatian terhadap potensi-potensi anak, sehingga agar terjadi interaksi orangtua dengan anak dalam pengembangan potensi pada diri anak. (Arief Rifkiawan Hamzah, 2016 ).

Berdasarkan pemaparan diatas, peneliti menganggap harus adanya kajian secara teoritis tentang tahapan dalam mendidik anak usia dini dari usia 0-6 tahun. Hal ini bertujuan agar orangtua dapat memahami dan berinteraksi dengan anak yang lebih mendalam dalam tahapan-tahapan anak usia dini. Untuk itu, penulis melakukan penelitian serta mengkaji terhadap pemikiran Ibnu Qayyim AlJauziyyah dalam pendidikan anak usia dini yang dapat berpengaruh pada mendidik anak melalui tahapannya.

Adapun peneliti memilih tokoh seorang Ibnu Qayyim Al-Jauziyah disebabkan oleh beberapa alasan diantaranya adalah: Pertama, Beliau merupakan tokoh agama yang menguasai berbagai cabang ilmu-ilmu keislaman( Moh.Syamsi, 2018), yang sangat berpedoman jika tokoh seorang Ibnu Qayyim Al-Jauziyyah diterapkan mendidik anak usia dini dalam segi religius. Kedua, karya Beliau sangat banyak sehingga menjadi sangat terkenal, juga pada karakteristik ciri dalam penulisannya sangat jelas dan nyata.( Rosidi 2019 ), dan dalam kitab Beliau yang salah satunya membahas tentang pendidikan anak usia dini. Ketiga, Ibnu Qayyim Al-Jauziyyah bukan hanya dalam Al-qur'an dan hadis pendekatan yang ditulis oleh Beliau, karya beliau yang masih sangat relevan dan bisa dipakai hingga masa yang akan datang. Keempat, ada beberapa tahapan dalam mendidik anak usia dini oleh orangtuanya untuk mengembangkan dan menumbuhkan segala potensi-potensi dan bakat yang ada pada diri anak ( Ibnu Qayyim, 2010).

Banyak hal yang menarikdari tokoh pemikiran pendidikan anak usia dini menurut Ibnu Qayyim Al-Jauziyyah yang untuk mengembangkan segala potensi anak dari sejak dini. Untuk itu, peneliti mengkajinya dalam sebuah judul: Pemikiran Pendidikan Anak Usia Dini Menurut Ibnu Qayyim Al-Jauziyyah.

\section{B. METODOLOGI}

Metode yang digunakan dalam penelitian adalah metode penelitian kepustakaan ( Library Research), dengan pendekatan kualitatif.Menurut Abdul 
J-SANAK: Jurnal Kajian Anak

(p-ISSN: 2686-5343 le-ISSN: 2715-7989)

Vol. (1)(2), (Januari-Juni)(2020), (Halaman)(47-61)

DOI: https://doi.org/10.24127/j-sanak.v1i02.203

Rahman Sholeh penelitian kepustakaan merupakan penelitian yang menggunakan cara dengan mendapatkan segala data informasi untuk menempatkan fasilitas yang ada di perpustakaan, seperti buku, majalah, dokumen, maupun catatan kisahkisah dari sejarah(Abdul Rahman Sholeh, 2005). Dari permasalahan yang dibahas, maka peneliti menggunakan pendekatan filosofis. Sehingga yang menjadi Objek dalam penelitian adalah pemikiran pendidikan anak usia dini menurut Ibnu Qayyim al-Jauziyah.

Pada teknik pengumpulan data, maka peneliti menggunakan bahan-bahan dokumentasi. Dan pada peneliti itu sendiri adalah sebagai instrument inti. Peneliti menggunakan kajian isi ( content analysis ). Menurut Hosti dalam Syamsul Ma'arif kajian isi ( content analysis ) merupakan yang digunakan sebagai menganalisis semua bentuk komunikasi seperti bahan-bahan dokumentasi dan lainnya(Syamsul Ma'arif, 2011).Untuk mendapatkan data yang valid, maka dapat diperoleh data dari segala literature-literature yang secara primer maupun sekunder sehingga diolah secara sistematis berupa dokumentasi melalui informasi yang menarik dan dipahami tentang adanya pendidikan yang menurut pemikiran Ibnu Qayyim terhadap anak usia dini 0-6 tahun . Dan data-data dapat diperoleh, yang kemudian peneliti mengolah data tersebut dengan cara membaca, mencatat serta menganalisis dengan menyimpulkan.

\section{HASIL DAN PEMBAHASAN}

Pendidikan untuk anak usia dini sangatlah penting untuk dilakukan. Pada masa usia dini merupakan masa keemasan (golden age) yang memiliki karakteristik yang ada pada anak yaitu rasa ingin tau ( Janet Currie, 2001 ).Maka dalam hal ini pendidik harus bisa mengembangkan potensi dari diri anak.Dengan memulai memberikan gizi yang baik kepada anak, serta stimulus-stimulus yang bisa mengembangkan potensi anak seperti dengan memberikan permainan yang memiliki nilai pendidikan atau fasilitas untuk anak.Dalam hal ini sangatlah berperan dengan pengaruh bagi pertumbuhan dan perkembangan anak.Agar disaat anak memasuki sekolah dasar sudah memiliki bekal dan kesiapan dalam belajar dalam pendidikannya anak.

Pendidikan anak usia dini merupakan anak yang mempunyai suatu bentuk stimulai dasarnya yaitu menciptakan lingkungannya melalui intervensi dengan mengstimulasi seluruh aspek perkembangan anak ( Janet Currie, 2001). Intervensi merupakan sejumlah infromasi anak yang telah diatur melalui pembelajaran, perkembangan maupun perubahan perilaku anak.

Pendidikan anak usia dini juga merupakan jenjang pendidikan sebelum 
J-SANAK: Jurnal Kajian Anak

(p-ISSN: 2686-5343 le-ISSN: 2715-7989)

Vol. (1)(2), (Januari-Juni)(2020), (Halaman)(47-61)

DOI: https://doi.org/10.24127/j-sanak.v1i02.203

jenjang pendidikan dasar yang upayanya dalam suatu pembinaan ditujukan bagi anak sejak lahir sampai usia anak enam tahun yang dapat dilakukan melalui pemberian rangsangan pendidikan untuk anak dalam membantu pertumbuhan dan perkembangan jasmani maupun rohani agar anak memiliki kesiapan disaat memasuki pendidikan lebih lanjut, yang diselenggarakan pada jalur formal, non formal, dan informal( Maimunah Hasan, 2011 ).

Pendidikan anak usia dini yang pada dasarnya dari pendidikan anak selanjutnya yang penuh dengan tantangan juga berbagai permasalahan yang dihadapi oleh anak. Hakekat anak usia dini merupakan suatu periode pendidikan yang sangat menentukan perkembangan anak dan arah masa depan seorang anak,karena dengan pendidikan yang anak mulai dari usia dini akan membekas dengan baik hingga masa perkembangannya dilalui dengan suasana yang baik, harmonis dan menyenangkan dalam mendidik.

Tujuan utama menurut Ibnu Qayyim dalam pendidikan anak adalah segala sesuatu yang dapat menumbuhkan dan menanamkan nilai moral dalam diri anak serta dapat mengembangkan seluruh potensinya juga memelihara fitrah sebagai anak, menjaganya dari sifat yang tercela sehingga dapat mengenal Allah SWT, yang terealisasikan perbuatannya tersebut dalam kehidupan sehari-hari anak. (Ridwan, 2016 ). Ibnu Qayyim Al-Jauziyyah dikenal sebagai orang yang tekun dalam mencari ilmu pendidikan maupun ilmu yang religius (Arikhah, 2016). Dengan segala ketaqwaan, kemuliaan, keshalihan serta kedamaian yang dimilikinya. Dan mempunyai ilmu dalam pemikiran pendidikan bagi anak usia dini ( Rusdaya Basri, 2015 ).

Tujuan pendidikan menurut Ibnu Qayyim merupakan yang mengarahkan dari orangtua kepada anak sejak dini melalui pendidikan yang bersifat religius, yang mengarahkan serta merealisasikan kearah keagamaan maupun akhlak dalam diri anak, yang dapat mengajarkan hal-hal ibadah yang paling dasar dan mudah dipahami oleh anak usia dini sehingga anak mengenal sang Pencipta-Nya serta berakhlakul karimah yang merupakan tujuan yang paling penting dalam pendidikan anak usia dini. ( Imron Rossidy, 2009).

Sejak usia dini anak telah dibekali dengan berbagai potensi-potensi yang harus dikembangkan dalam diri anak agar dapat menjalankan fungsi dan perannya sebagai manusia yang secara efektif dan produktif di dalam kehidupan sehariharinya pendidikan anak usia dini. Dalam pendidikan anak usia dini yang pada hakikatnya merupakan penerapan dalam pandangan-pandangan filsafat. Dalam arti lain, filsafat pendidikan anak usia dini adalah mengaplikasikan dalam analisis maupun kajian filsafat dalam penyelenggaraan pendidikan usia dini meyangkut kurikulum, aspek, pendidikan, tujuan pendidikan, objek pendidikan, pendekatan, 
J-SANAK: Jurnal Kajian Anak

(p-ISSN: 2686-5343 le-ISSN: 2715-7989)

Vol. (1)(2), (Januari-Juni)(2020), (Halaman)(47-61)

DOI: https://doi.org/10.24127/j-sanak.v1i02.203

model pembelajaran dan proses assesmen dalam pendidikan anak usia dini.

Pandangan Ibnu Qayyim melihat pendidikan terhadap anak sebagai upaya dalam mengembangkan dari potensi bawaannya.Anak membutuhkan orangtuanya untuk menentukan arahan dalam perkembangannya.Oleh karena itu, anak perlu adanya pengajaran dan dilatih agar dapat hidup berbagai potensi dan pendidikan yang didapat anak.dalam perkembangan anak membutuhkan interaksi sosial maupun interaksi religiusnya.

Keterkaitan pemikiran Ibnu Qayyim dalam pendidikan anak usia dini merupakan anak yang dalam tingkah lakunya dan hasil pengaruh lingkungan melalui perkembangana anak tergantung dengan lingkungannya sendiri. Jika lingkungan yang memelihara anak dengan baik, maka baiklah dalam perkembangan lingkungannya anak. Dan sebaliknya, jika anak berada dilingkungan belajar yang kurang bagus, maka anak akan kurang optimal juga dalam perkembangannya.

Dalam tarbiyahnya anak juga Ibnu qayyim berpendapat bahwa pendidikan anak khususnya adalah kebutuhan anak usia dini terhadap pendidikan. Sesungguhnya akhlak merupakan pembentukkan dasar pada masa anak usia dini. IbnuQayyim berkata: "Diantara yang dibutuhkan anak adalah dengan memperhatikan akhlaknya, karena anak usia dini akan berkembang sesuai dengan pembiasaan yang telah diajarkan oleh orangtuanya sejak usia dini, baik sifat emosional anak usia dini, egosentrisnya, dan lainnya. Maka jika anak usia dini akhlaknya bengkok ini merupakan pola asuhan atau pola pendidikannya dari sejak kecil”( Qosdi Ridhwanullah, 2009 ).

Ibnu qayyim juga berkata bahwasanya jika orang tua mengabaikan pendidikan anak, berarti orang tua telah memperlakukan anaknya dengan perlakuan yang mengabaikan pendidikan, terkhusus tentang pendidikan agama dan akhlak anaknya, sehingga menjadikan anak tersebut tidak lagi berguna bagi dirinya dan orang tuanya. Dalam hal ini, saling keterkaitan antara orangtua dan lingkungan anak, jika orang tua dari anak memberikan pendidikan sejak usia dini, maka anak akan menerima informasi sesuai yang ia lihat dan didengar dari lingkungannya. Untuk itu orang tua harus mengasuh dan membimbingnya dengan memberikan pendidikan yang bermanfaat khusunya pendidikan agama dan akhlak hingga dewasa anak akan tumbuh menjadi anak yang cerdas dan berakhlakkul karimah, dan pada akhirnya anak dapat dibanggakan di lingkungan sekitarnya(Ibnu Qayyim Al-Jauziyyah, 2009 ).

Dalam konteks pendidikan anak usia dini, tanggung jawab orangtua dalam mendidik anak usia dini adalah dengan bersabar dan seksama, serta dapat mengetahui segala kebutuhan maupun kesiapan dalam mendidik yang mampu 
J-SANAK: Jurnal Kajian Anak

(p-ISSN: 2686-5343 le-ISSN: 2715-7989)

Vol. (1)(2), (Januari-Juni)(2020), (Halaman)(47-61)

DOI: https://doi.org/10.24127/j-sanak.v1i02.203

mengasuh dan membimbing anak usia dini sejak lahir sampai berumur enam tahun adalah keharusan bagi orangtuanya. Hal ini dalam kitabnya Ibnu Qayyim tertulis bahwasanya: "Ajari dan didiklah anak-anakmu, sedangkan Hasan berkata: ajaklah mereka untuk taat pada Allah dan ajari mereka tentang kebaikkan"(Ibnu Qayyim Al-Jauziyyah , 2009, ).

Pada lingkungan pendidikan anak usia dini, tanggung jawab orangtua dalam mendidik anak sangat berperan dalam mengasuh dan membimbing anak usia lahir sampai 6 tahun(Ujang Endang, Indrawati Noor Kamila , 2018).

Ibnu Qayyim Al-Jauziyyah berpendapat terhadap tahapan yang harus dilakukan orangtua dalam mendidik anak dari usia 0-6 tahun.Pada masa awal perkembangan bagi seorang anak di masa menyusui. Seorang anak pertama kali lahir kedunia dipengaruhi oleh lingkungan disekelilingnya, dari apa yang menyentuh, bekerja, dan bergerak disekitarnya seperti berguling, duduk, berdiri, merangkak dan berjalan.. Anak pada usia ini harus benar-benar dijaga dari hal-hal yang membahayakan. Bayi yang masih lemah, harus selalu dijaga serta dilindungi dari setiap yang mengagetkannya, seperti suara-suara yang terlalu keras, pemandangan-pemandangan, dan gerakkan-gerakkan yang mengejutkan yang dapat membuat anak menakutkan Adapun tahapan yang harus dilakukan oleh orang tua dalam mendidik anak di usia 0-2 tahun menurut Ibnu Qayyim AlJauziyyah yaitu:

\section{Adzan di Telinga Kanan dan qamah di Telinga Kiri}

Pada zaman Rasulullah, adzan dan iqamah merupakan penyebaran dalam konsep pendidikan tauhid secara dini yang telah dikemukakan salah satunya oleh Ibnu Qayyim al-Jauziyyah.Dalam hal ini, cukup beralasan bahwasanya Ibnu Qayyim al-Jauziyyah menganggap ketauhidan yang diberikan sejak dini kepada anak sangat berpengaruh terhadap sikap maupun tingkah perilaku anak.

\section{Mentahnik Bayi}

Tahnik merupakan menggosok dengan lembut pada langit-langitnya mulut bayi yang baru dilahirkan dengan buah kurma yang telah dilumatkan padanya .Ibnu Qayyim berpendapat bahwa bayi yang baru lahir disunahkan dengan mentahnikkan buah kurma serta menggosok-gosokkan dilangit-langitnya mulut bayi dengan jari telunjuk, hingga secara perlahan telunjuk tersebut digerakkan kekanan dan kekiri.

\section{Mengaqiqahkan Anak}

Copyright @ 2020 , Universitas Muhammadiyah Metro| 53 
J-SANAK: Jurnal Kajian Anak

(p-ISSN: 2686-5343 le-ISSN: 2715-7989)

Vol. (1)(2), (Januari-Juni)(2020), (Halaman)(47-61)

DOI: https://doi.org/10.24127/j-sanak.v1i02.203

Ajaran yang telah disunnahkan yaitu dengan beraqiqah, sebab dengan pelaksaan aqiqah akan terjalin hubungan sillaturahmi antara kerabat maupun saudara dengan mengungkapkan rasa syukur orangtua anak yang telah dikaruniainya. Sebagaimana Nabi Muhammad SAW bersabda : " Setiap anak yang dilahirkan tergadai dengan aqiqahnya menebusnya dengan penyembelihan hewan aqiqah untuknya pada hari ketujuh dari kelahirannya dan diberi nama"(Angga Saputra dan Maemonah, 2019 ).Dengan berlandaskan hadis, bagi ibnu Qayyim sangatlah penting beraqiqah, karena didalamnya dapat mengandung unsur pendidikan keimanan kepada Allah serta dapat terjalin sosial dengan sesamanya.

\section{Mencukur Rambut Anak}

Dalam islam, ada beberapa adab untuk menyambut anak yang baru dilahirkan yaitu dengan mencukur rambutnya. Nabi Muhammad SAW bersabda:

"Seorang anak yang baru lahir tergadai dengan aqiqahnya, disembelih darinya ( kambing) pada hari ketujuh kelahiran anak, dicukur rambutnya dan diberi nama" ( HR. at-Tirmidzi ). Menurut ibnu Qayyim dengan mencukur rambut anak dapat menghilangkan kotoran. Dalam hal ini dengan membuang rambut yang jelek maupun lemah dapat menjadikan rambut anak akan kuat dan lebih bermanfaat bagi kepala bayi, juga dapat membuka lobang pori-pori dan menguatkan indera penglihatan, penciuman, dan pendengaran anak.

\section{Memberi Nama Baik Pada Anak}

Dalam pemberian nama baik untuk anak akan berpengaruh pada psikologis nya, seperti pada proses perkembangannya yang mengarah keadaan anak yang lebih baik ( Helda Nur Ania, 2016 ). Pemberian nama baik pada anak salah satu bentuk kemuliaan dan kebaikkan yang harus dilakukan, dikarenakan nama dan panggilan yang baik itu akan meninggalkan kesan yang positif dalam diri anak. Ibnu qayyim menggambarkan berdasarkan hadis Rasulullah, yaitu menyenangi dalam pemberian nama baik anak yang baru dilahirkan dengan nama-nama Nabi dan Asma' Allah agar nama anak mengandung doa yang baik. Bagi Ibnu Qayyim juga sangat penting bagi pendidikan anak terutama dalam pemberian nama, karena nama yang tidak baik akan mempengaruhi secara psikologis anak, seperti adanya kemindera, serta tidak percaya diri hingga menutup diri dari pergaulannya.

\section{Menyusui Hingga Dua Tahun}

Copyright @ 2020 , Universitas Muhammadiyah Metro| 54 
J-SANAK: Jurnal Kajian Anak

(p-ISSN: 2686-5343 le-ISSN: 2715-7989)

Vol. (1)(2), (Januari-Juni)(2020), (Halaman)(47-61)

DOI: https://doi.org/10.24127/j-sanak.v1i02.203

Menyusui anak merupakan kerja fisik dan psikis mempunyai peranan serta pengaruh yang amat besar bagi pertumbuhan fisik anak, mental maupun kepribadian anak. Dalam pandangan Ibnu qayyim memberikan ASI sebagaimana sunnah Rasul dengan memberikan ASI selama dua tahun, akan menghasilkan anak yang kuat serta memiliki daya imunitas yang tinggi bagi anak. Selain itu, ibu juga bisa mendidik anaknya secara langsung dengan proses menyusui anak selama 2 tahun tersebut.

\section{Mengkhitan Anak}

Khitan merupakan memotong kulit yang menutupi pada ujung kemaluan dengan tujuan agar anak bersih dari najisnya. Menurut pendapat Ibnu qayyim , khitan wajib dilakukan oleh orangtua kepada anaknya, agar terhindar dari penyakit serta gangguan kesehatan lainnya. Selain itu juga agar anak mudah dalam bersuci ketika sehabis buang air kecil.

Ibnu Qayyim Al-Jauziyyah juga berpendapat terhadap tahapan yang harus dilakukan orang tua dalam mendidik anak pada usia 3-6 tahun. Pada masa usia anak 3-6 tahun sangat peka dan mudah dalam meniru, terutama apa yang telah menjadi kebiasaan anak.Dalam perkembangan anak aspek yang sangat berhubungan dengan anak yaitu orangtua terhadap pendidikan anak. Ibnu Qayyim menegaskan tentang adanya bertanggung jawab anak usia dini hingga kelak nanti ia sudah dewasa yaitu : " Pada hari kiamat Allah SWT, bertanya kepada orangtua perihal anaknya sebelum sang anak bertanya perihal orangtuanya. Karena , anak mempunyai hak dan kewajiban ditunaikan oleh orangtuanya. Maka, barang siapa yang tidak mengajari anaknya sesuatu yang bermanfaat, atau membiarkan dalam pendidikannya. Berarti orangtua sudah merusak anak. Kebanyakkan anaknya rusak dikarenakan ulah dari orangtuanya yang mengabaikan pendidikan anak sejak dini”(Ibnu Qayyim Al-Jauziyyah, 2009 ).

Dalam hal ini ada beberapa tanggung jawab bagi orangtua terhadap pendidikan anak menurut ibnu Qayyim diumur 3-6 tahunyaitu :

\section{Tanggung Jawab Pendidikan Iman}

Di dalam lingkungan pendidikan anak usia dini, mengenai pendidikan keimanan anak haruslah ditanamkan sejak dini, agar pendidikan iman dapat menumbuhkan dan membiasakan anak mengajarkan tentang dasar-dasar dalam syariat islam. Ibnu Qayyim berkata bahwa " Bilaanak dilatih disaat awal berbicaranya dengan kalimah 'La Illaha Ilallah' maka hendaknya kalimah yang 
J-SANAK: Jurnal Kajian Anak

(p-ISSN: 2686-5343 |e-ISSN: 2715-7989)

Vol. (1)(2), (Januari-Juni)(2020), (Halaman)(47-61)

DOI: https://doi.org/10.24127/j-sanak.v1i02.203

pertama kali ia dengar tentang pengenalan kepada Allah, mentauhidkan-Nya. Dan nama yang paling Allah cintai adalah Abdullah dan Abdurrahman agar ketika anak dipanggil dengan nama tersebut ia mengerti dan faham bahwasanya ia merupakan seorang hamba Allah, karena Allah lah Dzat yang Maha Pengasih dan Dia-lah Maha Pemelihara juga PenjagaNya"

\section{Tanggung Jawab Pendidikan Fisik}

Kewajiban lain yang harus diberikan kepada anak yaitu tanggung jawab pendidikan fisik.Pandangan Ibnu Qayyim terhadap tanggung jawab dalam pendidikan fisik yaitu dengan menitik beratkan kepada anak bahwasanya harus memperhatikan aspek kesehatan dalam diri anak, sehingga berimplikasikan pada adanya upaya untuk mengmaksimalkan aktifitas fisik anak dalam membangun kompetesensinya. Beliau juga memandang layanan pendidikan anak usia dini harus mencukup pelayanan kesehatan dan latihan ketangkasan serta kekuatan fisik, agar daya dalam kreatifitas anak dapat tumbuh berkembang dengan baik.

\section{Tanggung Jawab Pendidikan Sosial}

Dalam pendidikan pendidikan sosial anak harus di didik sejak dini agar menjalankan perilaku sosial dan dasar-dasar kejiwaan anak yang mulia dan bersumber pada akidah Islamiyah yang kekal dengan kesadaran iman.Ibnu qayyim berpendapat bahwa anak harus di didik untuk rajin, tidak malas dan nganggur.Tetapi anak di ajarkan sesuatu kegiatan atau aktivitas yang dapat membangun mental anak dan memberikan imajinasi pada diri anak dalam membangun kreativitas anak.Karena suatu saat anak ketika dewasa terbiasa bekerja keras sehinnga tidak ada pengangguran.Anak juga harus dilatih sejak dini, agar peduli pada lingkungan sekitarnya dengan menjaga kebersihan, menjaga serta melestarikan tanaman, dan mengajarkan anak agar sayang kepada binatang juga makhluk hidup lainnya.

\section{Tanggung Jawab Pendidikan Intelektual}

Anak yang dilahirkan telah diperintahkan untuk mengajarkan dasar-dasar kesehatan jiwa anak yang memungkinkan ia dapat menjadi anak yang berilmu , berakal, berfikir sehat, serta berkemajuan tinggi.Penjelasan Ibnu Qayyim bahwasanya peran orangtua sangat berperan dalam upaya mengembangkan minat dan bakat anak dalam merangsang perkembangan otak anak dengan mengisi berbagai aktivitas-aktivitas positif dalam diri anak sesuai dengan tingkat usianya.

Dalam memberikan pendidikan intelektual kepada anak, yang orang tua 
J-SANAK: Jurnal Kajian Anak

(p-ISSN: 2686-5343 le-ISSN: 2715-7989)

Vol. (1)(2), (Januari-Juni)(2020), (Halaman)(47-61)

DOI: https://doi.org/10.24127/j-sanak.v1i02.203

wajib mendidik anak hingga melatih kecerdasan otaknya.Oleh karena itu, orangtua harus selalu memotivasi anak untuk terus mengembangkan bakat serta kemampuannya, sehingga kelak anak dapat membahagiakan orangtuanya juga bermanfaat bagi orang yng ada disekitanya. Dengan begitu bagi Ibnu qayyim pendidikan intelektual sangatlah penting bagi anak usia dini, agar mereka nanti mampu berfikir secara kritis dan mempunyai landasan ilmu yang berguna bagi Bangsa dan Negara.

Berdasarkan hasil penelitian pendidikan anak usia dini menurut pemikiran Ibnu qayyim sangat penting bagi pendidikan anak sejak dini. Karena pada pendidikan anak sejak dini dapat berpengaruh bagi perkembangan anak sejak dini hingga dewasa nanti ditahap selanjutnya. Maka pendidikan pertama yang didapat oleh anak adalah pendidikan yang diberikan oleh keluarga yang peran utamanya orangtua dari anak serta di lingkungannya yang baik ( Muhammad Abdullah, 2017). Oleh karena itu, keluarga maupun orangtuanya dapat menjadi peran dalam bertanggung jawab bagi anak usia dini yang memberikkan pendidikan dengan baik sehingga anak dapat mengembangkan segala potensinya menjadi anak yang berakhlakul karimah, cerdas, dan mematuhi segala aturan dalam agama islam. Ibnu qayyim berpendapat bahwa pada anak lahir hingga usia enam tahun, ada beberapa stimulus yang harus diberikan meliputi :

Tabel 1.

Pendidikan anak usia 0-6 Tahun

\begin{tabular}{|c|l|l|}
\hline No & \multicolumn{1}{|c|}{ Materi Pendidikan } & $\begin{array}{c}\text { Pencapain Perkembangan } \\
\text { Anak }\end{array}$ \\
\hline 1 & Mengumandangkan Adzan dan iqamah & Moral dan NAM \\
\hline 2 & Mentahnik bayi & Fisik Motorik \\
\hline 3 & Mengaqiqah anak & NAM dan Sosial \\
\hline 4 & Mencukur rambut anak & NAM \\
\hline 5 & Memberi nama baik pada anak & Sosial Emosional, NAM \\
\hline 6 & Menyusui hingga dua tahun & Fisik,Emosional,dan Kognitif \\
\hline 7 & Mengkhitan anak & NAM,Fisik Motorik \\
\hline 8 & Tanggung jawab pendidikan iman & Bahasa, NAM \\
\hline 9 & Tanggung jawab pendidikan fisik & Fisik Motorik \\
\hline 10 & Tanggung jawab pendidikan sosial & Sosial Emosional \\
\hline 11 & Tanggung jawab pendidikan intelektual & Kognitif \\
\hline
\end{tabular}

Berdasarkan tabel diatas dapat disimpulkan bahwa dengan memberikkan pendidikan anak sejak lahir hingga usia 0-6 tahun menurut Ibnu Qayyim alJauziyah yaitu mulai usia 0-2 tahun dengan: (1) Adzan di telinga kanan dan iqamah di telinga kiri agar ketauhidan yang diberikan sejak dini kepada anak sangat berpengaruh terhadap sikap maupun tingkah perilaku anak, (2) Mentahnik 
J-SANAK: Jurnal Kajian Anak

(p-ISSN: 2686-5343 le-ISSN: 2715-7989)

Vol. (1)(2), (Januari-Juni)(2020), (Halaman)(47-61)

DOI: https://doi.org/10.24127/j-sanak.v1i02.203

bayi dengan mentahnikkan buah kurma serta menggosok-gosokkan dilangitlangitnya mulut bayi dengan jari telunjuk, hingga secara perlahan telunjuk tersebut digerakkan kekanan dan kekiri sesuai dengan ajaran Rasulullah SAW agar anak tidak adanya kekurangan glukosa pada diri anak. (3) Mengaqiqahkan anak karena didalamnya dapat mengandung unsur pendidikan keimanan kepada Allah serta dapat terjalin sosial dengan sesamanya. (4) Mencukur rambut anak agar anak memperkuat rambut anak dan mengikuti sunahnya. (5) Memberi nama baik pada anak agar dalam pemberian nama baik anak yang baru dilahirkan dengan nama-nama Nabi dan Asma ${ }^{e e}$ Allah agar nama anak mengandung doa yang baik. (6) Menyusui hingga dua tahun agar menghasilkan anak yang kuat serta memiliki daya imunitas yang tinggi bagi anak. Selain itu, ibu juga bisa mendidik anaknya secara langsung dengan proses menyusuianya selama 2 tahun tersebut. (7) Mengkhitan anak agar terhindar dari penyakit serta gangguan kesehatan lainnya. Selain itu juga agar anak mudah dalam bersuci ketika sehabis buang air kecil sesuai dengan ajaran Nabi Muhammad SAW.

Pada pendidikan anak 3-6 menurut Ibnu Qayyim al-Jauziyah yaitu dengan tanggung jawab pendidikan iman, dengan menumbuhkan dan membiasakan anak mengajarkan tentang dasar-dasar dalam syariat islam dan lafadz kalimah "La Illaha Ilallahee maka hendaknya kalimah yang pertama kali ia dengar tentang pengenalan kepada Allah, mentauhidkan-Nya. (2) Tanggung jawab pendidikan fisik agar mencukup pelayanan kesehatan dan latihan ketangkasan serta kekuatan fisik, agar daya dalam kreatifitas anak dapat tumbuh berkembang dengan baik. (3) Tanggung jawab pendidikan sosial agar peduli pada lingkungan sekitarnya dengan menjaga kebersihan, menjaga serta melestarikan tanaman, dan mengajarkan anak agar sayang kepada binatang juga makhluk hidup lainnya. (4) Tanggung jawab pendidikan intelektual agar mampu berfikir secara kritis dan mempunyai landasan ilmu yang berguna bagi Bangsa danNegara.

\section{KESIMPULAN}

Dalam dunia pendidikan dan pengajaran, dimana pengajaran lebih menitik beratkan pada proses transformasi pengetahuan, sementara pendidikan lebih umum dari pengajaran karena di dalamnya juga tercakup nilai dan sikap dari sebuah pendidikan tersebut. Pendidikan anak usia dini merupakan anak yang mempunyai suatu bentuk stimulai dasarnya yaitu menciptakan lingkungannya melalui intervensi dengan mengstimulasi seluruh aspek perkembangan anak.

Tujuan pendidikan anak usia dini adalah suatu saat nanti anak akan memiliki kesiapan dalam memasuki pendidikan lebih lanjut, yang meliputi dalam 
J-SANAK: Jurnal Kajian Anak

(p-ISSN: 2686-5343 |e-ISSN: 2715-7989)

Vol. (1)(2), (Januari-Juni)(2020), (Halaman)(47-61)

DOI: https://doi.org/10.24127/j-sanak.v1i02.203

pertumbuhan dan perkembangan anak baik dalam jasmani maupun rohaninya. Pandangan Ibnu Qayyim melihat pendidikan terhadap anak sebagai upaya dalam mengembangkan dari potensi bawaannya.Anak membutuhkan orangtuanya untuk menentukan arahan dalam perkembangannya.Oleh karena itu, anak perlu adanya pengajaran dan dilatih agar dapat hidup berbagai potensi dan pendidikan yang didapat anak.dalam perkembangan anak membutuhkan interaksi sosial maupun interaksi religiusnya.

Keterkaitan pemikiran Ibnu Qayyim dalam pendidikan anak usia dini merupakan anak yangdalam tingkah lakunya dan hasil pengaruh lingkungan melalui perkembangana anak tergantung dengan lingkungannya sendiri. Jika lingkungan yang memelihara anak dengan baik, maka baiklah dalam perkembangan lingkungannya anak. Dan sebaliknya, jika anak berada dilingkungan belajar yang kurang bagus, maka anak akan kurang optimal juga dalam perkembangannya.

Pendidikan pada anak usia dini menurut pemikiran Ibnu Qayyim merupakan pendidikan anak usia dini yang diterapkan kepada anak pada usia 0-6 tahun yaitu menjadi dua masa yaitu: a) Masa usia 0-2 tahun dengan memberikan perhatian kepada anak dengan stimulus melalui rangsangan baik itu nama,suasana agamis dan pengasuhan seperti mentahnik, mengakikahkan dan mengkhitan anak. b) Masa usia 3-6 tahun adalah orang tua yang memberikkan perhatian kepada anak dengan mendidik meliputi 5 aspek tanggung jawab yaitu: tanggung jawab dalam pendidikan iman, tanggung jawab pendidikan akhlak, tanggung jawab pendidikan sosial, tanggung jawab pendidikan fisik dan tanggung jawab pendidikan intelektual.

\section{E. DAFTAR PUSTAKA}

Abdullah, Muhammad. (2017). Pendidikan Prenatal: Telaah Pemikiran Ibnu Qayyim al-Jauziyyah dalam Kitab Tuhfah Al-Maudud bi Ahkam AlMaulud dan Relevansinya Dengan Pendidikan Islam. Jurnal al-Murabbi Vol 2,(2): 344.

Anggraeni Islami Anggi, Rosyad Rifki. (2018). Pendidikan Anak Perspektif Sufistik Dalam Pandangan Ibnu Qayyim Al-Jauziyyah. Jurnal Syifa AlQulub Vol 4,(2): 34-48.

Ania, Helda Nur. (2016). Psikologi Perkembangan Anak Perspektif Ibnu Qayyim Al-Jauziyyah ( Kajian Kitab Tuhfat al-Maudud bi Ahkam al-Maulud ). Jurnal Pendidikan Islam Al I'tibar Vol 2,(1): 38-55.

Arikhah.(2016). Reaktualisasi Pemikiran Ibn Qayyim Al-Jauziyyah dalam

Pengembangan Tasawuf. Jurnal at-Taqaddum Vol 8,(1): 73-89.

Copyright @ 2020 , Universitas Muhammadiyah Metro| 59 
J-SANAK: Jurnal Kajian Anak

(p-ISSN: 2686-5343 le-ISSN: 2715-7989)

Vol. (1)(2), (Januari-Juni)(2020), (Halaman)(47-61)

DOI: https://doi.org/10.24127/j-sanak.v1i02.203

Aslan.(2019). "Peran Pola Asuh Orangtua di Era Digital”. Yogyakarta: Jurnal Studia Insania, Vol 07, (1): 21. DOI: 10.18592/jsi.v7i1.2269

Basri, Rusdaya. (2015). Ibnu Qayyim Al-Jauziyyah tentang Pengaruh Perubahan Sosial. Jurnal Al-Manahij Vol 9,(2): 195.

Currie, janet, (2001) Early Childhood Education Programs, University of California at Los Angeles: Jurnal of Education . Vol 15,(2): 213-238.

Hamzah, Arief Rifkiawan.(2016). Pendidikan Prenatal Menurut Ibnu Qayyim Al-Jauziyyah dan Implikasinya Terhadap Perkembangan Potensi Anak. Yogyakarta: UIN Sunan Kalijaga.

Hasan,Maimunah. (2011). PAUD Pendidikan Anak Usia Dini .Yogyakarta: DIVA Press.

Kholil, Ahmad. (2006). Studi Islam dan Kebudayaan Manusis di Muka Cermin Ibnu arabi. Jurnal el-Harokah Vol 6,(3): 6-7.

Ma'arif Syamsul.( 2011). Mutiara-Mutiara Dakwah KH Hasyim Asy'ari. Bogor: Kanza Publishing.

Maemonah dan Angga Saputra, ( 2019) Pendidikan Untuk Anak Usia 0-2 Tahun Dalam Perspektif Ibnu Qayyim Al-Jauziyyah. Inonesian Journal of Islamic Early Childhood Education, Vol. 4, ( 2): 152 .

Mansur. (2014). Pendidikan Anak Sejak Dalam Kandungan. Yogyakarta: Mitra Pustaka.

Mappa Syamsu,dick. (1984). Teori Belajar Mengajar.Jakarta: Departemen Pendidikan dan Kebudayaan.

Qayyim Al-Jauziyyah , Ibnu.( 2009). Tuntunan Rasulullah dalam Mengasuh Anak, Terj.Tuhfatul Maulud Bi Ahkamil Maulud oleh Nabhani Idris. Jakarta: Studia Press.

Qayyim Al-Jauziyyah , Ibnu.( 2009). Tuntunan Rasulullah dalam Mengasuh Anak, Terj.Tuhfatul Maulud Bi Ahkamil Maulud oleh Nabhani Idris. Jakarta: Studia Press.

Qayyim Al-Jauziyyah, Ibnu. (2009). Tuntunan Rasulullah dalam Mengasuh Anak.Jakarta: Studia Press.

Qayyim, Ibnu. (2010). Uddatus Shabirin Alih Bahasa Imam Firdaus Bekal Untuk Orang-Orang yang Sabar.Jakarta: Qisthi Press.

Rahman Sholeh Abdul.( 2005). Pendidikan Agama dan Pengembangan untuk Bangsa. Jakarta: PT Raja Grafindo Persada.

Ridhwanullah,Qosdi. (2009). Tuhfatul Maudud Bi Ahkamil Maulud "Kado Sang Buah Hati “. Solo: Al-Qowwam.

Ridwan. (2016). Pendidikan Karakter Menurut Perspektif Imam Ibnu Qayyim Al-Jauziyyah . Jurnal Studi Islam Vol 1,(2): 42.

Copyright (C) 2020, Universitas Muhammadiyah Metro| 60 
J-SANAK: Jurnal Kajian Anak

(p-ISSN: 2686-5343 |e-ISSN: 2715-7989)

Vol. (1)(2), (Januari-Juni)(2020), (Halaman)(47-61)

DOI: https://doi.org/10.24127/j-sanak.v1i02.203

Rosidi.(2019). "Konsep Pendidikan Anak Prasekolah Dalam Perspektif Ibn Qayyim Al-Jawziyyah". Bangka Belitung: Jurnal Pendidikan Islam, Vol 6, (1): 21. DOI: 10.32923/tarbawy.v6i1.869

Rossidy, Imron. (2009). Analisis Komparatif Tentang Konsep Pendidikan Anak Menurut Ibnu Qayyim Al-Jauziyyah dan Al-Ghazali: Implikasinya Terhadap Pendidikan Agama Islam Kontemporer. Retrieved from .http://ejournal.uin.malang.ac.id/index.php/research/search/authors/

Syamsi, Mohd. (2018). Konsep Pendidikan Agama Islam Studi Atas Pemikiran Ibnu Qayyim Al-Jawziyyah. Jurnal Attaqwa Vol 14,(2): 26.

Ujang Endang dan Indrawati Noor Kamila. (2018). Konsep Pendidikan Anak Usia Dini Menurut Ibnu Qayyim Al-Jauziyyah, Tarbiyah Aulad, Vol. 3 (1): 6 . 